\title{
DOUĂ NOI SIGILII DE PLUMB DESCOPERITE ÎN DOBROGEA
}

\author{
Eugen Paraschiv-Grigore
}

\section{TWO NEW LEAD SEALS FOUND IN DOBROGEA}

The author presents two lead seals from the Bucharest Archeological Institut "Vasile Pârvan". The first seal was found at Tropaeum Traiani, a roman-byzantine center from the lower Danube. This is the first seal found in this site. The second seal was found by Petre Diaconu in the fortress of Păcuiul lui Soare, a byzantine center from the lower Danube. It is not the first seal from this city.

Keywords: lead seal, Tropaeum Traiani, Păcuiul lui Soare, roman-byzantine, byzantine. Cuvinte cheic: sigiliu, plumb, Tropaeum Traiani, Păcuiul lui Soare, romano-bizantin, bizantin.

\section{Tropaeum Traiani (Adamclisi, jud. Constanta)}

Cercetările făcute de-a lungul timpului în cetatea Tropaeum Traiani (Adamclisi, jud. Constanţa) au scos la iveală numeroase obiecte, dintre care o importanfă aparte o prezintă un sigiliu în ,alb”" . Aceasta deoarece este primul sigiliu descoperit până în momentul de faţă la Tropaeum Traiani, o altă descoperire de acest tip din perimetrul sitului nemaifiind consemnată. Astfel de sigilii în alb au mai fost însă descoperite pe teritoriul dobrogean şi publicate în reviste de specialitate $^{2}$.

În vara anului 1988, în urma săpăturilor arheologice efectuate în sectorul de sud-est al cetăţii Tropaeum Traiani (cunoscut şi ca sectorul „Mihai Sâmpetru”), într-una dintre încăperile edificiului $\mathrm{D} 7$, încăpere denumită D7j (în jumătatea de sud a ei), a fost descoperit acest mic obiect. Piesa se găsea ,sub baza lespezilor mari de lângă zidul de sud - până la

\footnotetext{
' Sigiliile în alb sunt plumburi ce nu au fost imprimate.

2 Barnea 1960. nr. 6 și 7: Constantiniu, Panait 1965. lig. 47: Papasima 1982: Damian 1992.
}


descoperire indică faptul că piesa datează din ultima fază de locuire a identificată în acest sector sau puţin înainte de această ultimă fază de locuire ${ }^{4}$. În urma reamenajării ,depozitului Sâmpetru" a fost posibilā „redescoperirea" acestei piese şi inventarierea $\mathrm{ei}^{5}$. Astfel, piesa a intrat în patrimoniul Institutului de Arheologie „Vasile Pârvan”, fondul Mihai Sâmpetru, cu numărul de inventar 145 MS (fig. 1). Sigiliul are formă discoidală şi un diametru de $22 \mathrm{~mm}$, grosimea este de circa $3 \mathrm{~mm}$, iar greutatea de 9,45 g. Starea de conservare a acestei piese este precară, pe ambele feţe existând urme de deteriorare lăsate de un obiect dur. Pe una din feţe se observă faptul că avea marginea uşor înălţată, lucru întâlnit la sigiliile în $\mathrm{alb}^{6}$. Din păcate, datorită deteriorării, canalul pentru şnur nu se distinge foarte bine, prezenţa acestuia fiind vizibilă doar la una dintre extremităţi.

Sigiliul se datează în ultima perioadã de existenţă a cetăţii, mai precis în secolele V-VI,

\footnotetext{
${ }^{3}$ Prezenta descriere se găsea pe pachetul cu materiale descoperite în încăperea amintită mai sus. notită consemnată de Mihai Sâmpetru la dala de 22 iulie 1988.

${ }^{4}$ Sâmpetru 1994, 15-16.

5 Plumbul a fost gāsit printre materialele mảrunte ce au fost descoperite în sectorul de sud-est al cetāţii. Identilicarca a fosı posibilă datoritã faptului cã pachetul în care se afla plumbul conţinea detalii ale modului de descoperire. precum şi marcajul aferent.

${ }^{6}$ Papasima 1982, 236.
} 
perioadă în care este datat şi cartierul de sudest cercetat de Mihai Sâmpetru? .

Ceea ce este interesant la sigiliile în „alb" descoperite până acum este faptul că aproape toate sunt datate în secolele $\mathrm{X}-\mathrm{XI}^{\mathbf{8}}$, fiind descoperite în cetăţile bizantine de pe teritoriul dobrogean sau cum este cazıl celui descoperit la Băneasa-Bucureşti, într-o aşezare medievală din secolele $\mathrm{X}-\mathrm{XI}^{9}$. Sigiliul de la Tropaeum Traiani nu poate să aparțină acestei perioade datorită contextului arheologic în care a fost descoperit ${ }^{10}$ şi, prin urmare, este prima piesă de acest fel găsită în Dobrogea.

Importanţa acestei piese este cu atât mai mare cu cât, până în momentul de faţă, nu se cunoaşte o ,altă" descoperire sigilară din perimetrul sitului de la Adamclisi. Faptul că acest sigiliu în alb a fost descoperit în săpătură, sub lespezile de piatră de lângă ,zidul de sud $^{\prime \prime \prime}$, indică faptul că sigiliul nu a fost adus din altă parte într-o perioadă ulterioară.

Existenţa unui sigiliu în „alb” în această zonă are două explicaţii pauzibile. Prima ar fi faptul că trebuie să fi existat un personaj ce bătea sigilii pentru corespondenţa proprie. Cea de-a doua explicaţie, mult mai plauzibilă datorită contextului descoperirii, este cea a unui sigiliu în ,alb” ce urma să fie folosit la sigilarea unor mărfuri. Acest lucru este evidenfiat de caracterul comercial al edificiului D7, unde a fost descoperit. În încāperile acestui edificiu, mai precis în $D 7 j$, au fost descoperite mai multe ustensile ce serveau la obţinerea vinului prin prelucrarea strugurilor, precum şi o râşniţă pentru măcinarea cerealelor $^{12}$.

\footnotetext{
${ }^{7}$ Sâmpetru 1994. 15-16.

"Sigiliul în ..alb" publicat de Tudor Papasima şi descoperit la Păcuiul lui Soare nu este datat pentru cã nu a fost descoperit într-un context arheologic, ci întâmplător. Dar oricum, fiind descoperit la Păcuiul lui Soare, se poate data tot în perioada medievală.

${ }^{9}$ Constantiniu. Panait 1965, 130.

${ }^{10}$ Se cunoaște loarte bine laptul cá locuirea în cetatea Tropaeum Traiani îşi incetează existenţa la sfârşitul secolului al VI-lea sau cel mai târziu la începutul secolului al VII-lea; Barnea 1979, 5-15.

"Zidul de sud al încăperii D7j, vezi Sâmpetru 1994. schifa ediliciului D7

12 Sâmpetru 1994. 45-46..
}

Fiind vorba de un sigiliu în ,alb”, putem spune că el nu a fost folosit la aducerea unei scrisori sau la aducerea unor produse comerciale, ci era folosit pentru expedierea unor asemenea produse. Existenţa unui sigiliu în alb presupune şi existenţa unui cleşte pentru imprimarea acestuia ${ }^{13}$. Din păcate, descoperirile de astfel de obiecte sunt rare, până în prezent fiind publicată o singură piesă găsită în zona Dunării de Jos, mai precis în Bulgaria $^{14}$.

\section{Păcuiul lui Soare (jud. Constanţa)}

Plumbul de faţă face parte din patrimoniul Institutului de Arheologie „Vasile Pârvan" din Bucureşti (fig. 2) ${ }^{15}$.

Sigiliul a fost descoperit întâmplător de către Petre Diaconu în perimetrul sitului arheologic de la Păcuiul lui Soare (cel mai probabil pe insulă). Din păcate, nu se mai cunosc alte detalii cu privire la locul exact şi condiţiile de descoperire ale acestui sigiliu ${ }^{16}$.

$\mathrm{Nu}$ este singurul sigiliu găsit în cetatea de la Păcuiul lui Soare ${ }^{17}$. Numărul mare de astfel de descoperiri în fortăreaţa de la Dunăre se datorează rolului important al acesteia, atât din punct de vedere comercial, cât şi militarstrategic, religios şi administrativ în cadrul

\footnotetext{
${ }^{13}$ Tehnica de imprimare a sigiliilor era puţin diferită fạ̧ă de tehnica de batere a monedelor. Astfel, dacă la monede se folosea o matrice, la sigilii se folosea un cleşte pe al căror braţe era imprimat în negativ legenda sigiliului. Pe unul dintre braţele cleştelui se decupa aversul. iar pe celălalt braţ. reversul. Pastila de plumb cra introdusã în cleşte şi prin presare se şantąa sigiliul. Plumbul cra lolosit ca material pentru confecţionarea sigiliilor deoarece acesta. după cum se ştic, este un metal moale ce poate fi imprimat uşor. În schimb, cleştele era confectionat dintr-un metal dur, pentru a rezista mai mult în timp. De obicei, aceşti cleşti erau făcuţi din fier. Aceste piese erau dȩ̣inute de către un personaj care îşi şıınta singur sigiliile. Cel mai probabil el achizitiona sigiliile în ..alb“ pe care le personaliza şi le utiliza la sigilarea corespondenı̣ sau a mărfurilor.

14 Iordanov 1992. 387.

is Sigiliul ne-a fost oferit spre publicare de către doamna dr. Oana Damian, căreia îi mulụunim şi pe această cale.

${ }^{16}$ Petre Diaconu nu precizează zona exactā în care a fost descoperit plumbul.

${ }^{17}$ Barnea 1960. nr. 3-7; Diaconu 1968; Papasima 1982; Barnea 1987. nr. 8 şi 9; Barnea 1990, nr. 19; Damian 1992.
} 
Imperiului Bizantin, în perioada secolelor $\mathrm{X}-\mathrm{XII}{ }^{18}$.

Forma sigiliului este discoidală, cu marginile uşor înălţate, străbătut pe toată lungimea diametrului său de un canal cilindric, prin care era petrecut şnurul. Are un diametru de $22 \mathrm{~mm}$, grosimea de circa $4 \mathrm{~mm}$ şi o greutate de 6,79 g. Starea de conservare este relativ bună, fiind uşor deteriorat (ros) în partea de sus dreapta a aversului (respectiv partea de sus stânga a reversului).

$O$ altă intervenţie asupra sigiliului se poate observa în partea superioară a acestuia, zonă ce prezintă două orificii perforate, de circa $3 \mathrm{~mm}$ diametru. Acestea străpung sigiliul dintr-o parte în cealaltă. Probabil cele două orificii au fost date cu scopul de a lega sigiliul la gât sau la mână, drept amuletă sau medalion. Marginea sigiliului este pronunţată formând un chenar circular, ccea ce denotă faptul că acesta a fost imprimat atât pe avers, cât şi pe revers. Extremităţile canalului pentru şnur, ce traversează plumbul pe diagonală, sunt știrbite. Sigiliul prezintă pe una din feţe urmele vagi alc siluetei unui sfânt, care, din păcate, datorită deteriorării, nu poate $f i$ identificat. Această dovadă de prelucrare conduce la concluzia că sigiliul a fost la un moment dat în uz, poate pentru a sigila o scrisoare sau nişte mărfuri, iar apoi, după ce îşi va fi îndeplinit această funcţie, a putut fi refolosit ca podoabă (amuletă/medalion).

${ }^{18}$ Diaconu. Vîlceanu 1972. 9-22. 


\section{BIBLIOGRAFIE}

Barnea 1960 - I. Barnea, Sigilii bizantine inedite din Dobrogea, StCercNum, 1960, 3, p. 323-332.

Barnca et alii 1979 - I. Barnea, Al. Barnea, I. Bogdan-Cătăniciu, Tropaeum Traiani. I. Cetatea, Bucureşti, 1979.

Barnea 1987 - 1. Barnea, Sceaux byzantins de Dobroudja, Studies in Byzantine Sigillography, Washington, Dumbarten Oaks (edited by N. Oikonomodés), 1987, p. 77-88.

Barnea 1990 -- I. Barnea, Sigilii bizantine inedite din Dobrogea (III), Pontica, 23, 1990, p. 315-334.

Constantiniu, Panait 1965 - M. Constantiniu, P. I. Panait, Şantierul arheologic Băneasa-Străulești, CAB, 2, 1965, p. $75-235$.

Damian 1992 - O. Damian, Despre un atelier de confectionat piese din plumn de la Păcuiul lui Soare, Pontica, XXV, 1992, p. 309-321.

Diaconu 1968 - P. Diaconu, Un sigiliu al lui Alexie I Comnenul descoperit la Păcuiul lui Soare, StCercNum, IV, 1968, p. 249-251.

Diaconu 1992 - P. Diaconu, Un alt sigiliu al lui Constantin Theodorokanos, Pontica, XXV, 1992, p. 359-361.

Diaconu, Vîlceanu 1972 - P. Diaconu, D. Vîlcceanu, Păcuiul lui Soare. Cetatea bizantină, I, Bucureşti, 1972.

Iordanov 1992 - Iv. Iordanov (Иван Йорданов), Оие ведньж за булотириона от Археологическия Музей a Codua (Encore une fois sur le boulotyrion du Musée Archeologique National à Sofia, GodMuzSof, VII, 1992, p. 387-393.

Papasima 1982 - T. Papasima, Despre sigiliile in alb din cetatea bizantină Păcuiul lui Soare (jud. Constanta), StCercIstorV, 33, 1982, 2, p. 236-237.

Sâmpetru 1994 - M. Sâmpetru, Oraşe şi cetăli romane târzii la Dunărea de Jos, Biblioteca Thracologie V, București, 1994.

\section{LISTA ILUSTRATTIEI}

Pl. 1 - 1. Sigiliu descoperit la Tropaeum Traiani (Adamclisi, jud. Constanța): a. avers; b. revers; 2. Sigiliu descoperit la Păcuiul lui Soare (Ostrov, jud. Constanţa): a. avers; b. revers.

\section{LIST OF ILLUSTRATION}

Pl. 1 - 1. Seal found at Tropaeum Traian (Adamclisi - Constanta county): a. front; b. reverse; 2 . Seal found at Păcuiul lui Soare (Ostrov - Constanta county): a. front; b. reverse

TRADUCERE REZUMAT, FOTO PIESE:

Eugen Paraschiv-Grigore

EUGEN PARASCHIV-GRIGORE

Muzeul Naţional de Istorie a României

Calea Victoriei, nr. 12, sector 3, 030026

Bucureşti

para_eugen@yahoo.com 


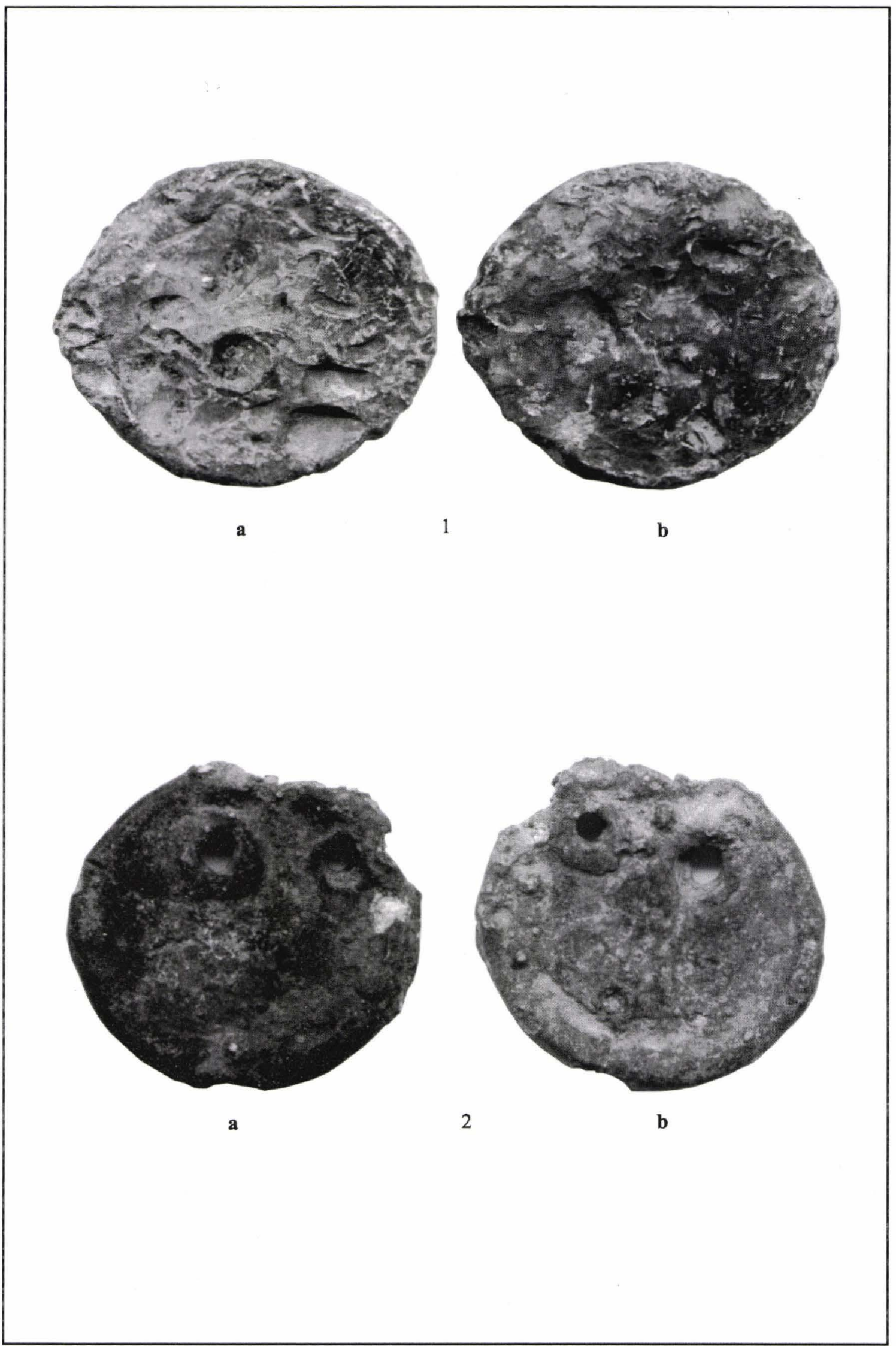

Pl. 1 - 1. Sigiliu de la Tropaeum Traiani: a. avers; b. revers; 2. Sigiliu de la Păcuiul lui Soare: a. avers; b. revers 
